\title{
Identity, Modernity, Communication: Contributions to Think Afro-Ecuadorian Cultural Identity
}

\author{
Bruno Santos N. Dias ${ }^{1, *}$, Pedro Fornaciari Grabois ${ }^{2}$ \\ ${ }^{1}$ College of Social Sciences and Humanities of the San Francisco University of Quito (USFQ), Quito, Ecuador \\ ${ }^{2}$ Federal Institute of Education, Science and Technology of Rio de Janeiro (IFRJ), Rio de Janeiro, Brazil
}

Copyright $(2018$ by authors, all rights reserved. Authors agree that this article remains permanently open access under the terms of the Creative Commons Attribution License 4.0 International License

\begin{abstract}
The objective of this paper is to analyze the Afro-Ecuadorian identity and how it conforms a political and theoretical place of objection and claim of fundamental importance. The paper progresses through three methodological stages. The first of these is a conceptual analysis of the notion of identity within a discussion about essentialism and the role of discourse in the making of race, racism and racial identities. Second, we discuss some notions related to the question of modernity to understand the exclusionary condition of blacks in the construction of the Ecuadorian state and its subsequent organizational processes, as well as to pinpoint the problematic definition of "miscegenation" and its debate in relation to perceptions about the Afro-Ecuadorian identity. The third stage proposes a contemporary view of this issue, where communication plays a constitutive role. Communication and its technological changes have accompanied and paved the way for the "progress" of modern societies for a long time, such that modernity itself would not be possible without technological communication. To this effect, communication guides us to an understanding of the dynamics of inclusion and exclusion, domination and resistance that come together to make this a racist country, while allowing us to observe various processes related to affirming Afro-Ecuadorian identities.
\end{abstract}

Keywords Afro-Ecuadorian Identity, Coloniality, Communication, Modernity

\section{Introduction}

The objective of this essay is to address the configuration of an Afro-Ecuadorian identity based on its historical, political and social context. We understand that communication is not just an additional element, but rather permeates the entire identity process with decisive importance. We begin by establishing a theoretical reflection of contemporary Ecuador, addressing the forms of racism existing towards black subjects and the place occupied by Afro-Ecuadorian identities. The journey begins by understanding contemporary racism and defining the place that racial identity occupies in "official" Western societies. From there, our attention is directed to Latin America and Ecuador, seeking to understand this country's process of moving into modern times based on a national construct born of certain points of reference. This narrative of the Ecuadorian nation, however, was not and is not set in stone, nor are changes thereto particularly restrictive; i.e, one narrative does not necessarily exclude or negate other versions. The way in which Ecuador is narrated throughout its existence as a National State has undergone changes and these narratives build upon one another. In this process of creating a national construct, Afro-descendants were assigned certain social roles in different ways based on different narratives. For example, this led to Afro-descendants in Ecuador to moving from being described as an "inferior race" during colonial times, to their current condition as a group having collective rights, as guaranteed under the most recent constitution.

However, this essay's perspective goes beyond the Ecuadorian particularities, finding that it is a process that has not been spontaneous, but rather something that has been closely affected by broader aspects that have affected Western societies as a whole, particularly those found in Latin America. Such aspects include coloniality, uprising of the masses, and cultural industries. More recently, these aspects include globalism and multiculturalism.

Here, we propose a reflection on how all these elements are shaping the place occupied by people of African descent in Ecuadorian society, and how social and cultural contexts, where communication plays a constitutive role, determine and are determined by these processes.

The paper progresses through three methodological stages. The first of these is a conceptual analysis of the notion of identity within a discussion about essentialism and the role of discourse in the making of race, racism and racial identities. Second, we discuss some notions related to the question of modernity to understand the exclusionary 
condition of blacks in the construction of the Ecuadorian state and its subsequent organizational processes, as well as to pinpoint the problematic definition of "miscegenation" and its debate in relation to perceptions about the Afro-Ecuadorian identity. The third stage proposes a contemporary view of this issue, where communication plays a constitutive role. Communication and its technological changes have accompanied and paved the way for the "progress" of modern societies for a long time, such that modernity itself would not be possible without technological communication.

\section{Race, Racism and Identity}

In the genealogy of racism suggested by Michel Foucault [1], modern racism is born of the passage of a "war of races" to "state racism", that is, of the passage of a discourse about races, mobilized against the State, towards a discourse about races ordered by the State. In the words of Negri \& Hardt [2] in Empire, contemporary racism has not declined or receded, but progressed in extension and intensity, changed in its strategic forms. They discuss a distinction between modern types of racism, whose Manichean divisions and rigid exclusionary practices (in South Africa and the South of the United States) were the paradigm, and racism in its postmodern form that is lived in the current imperial society, with their own strategies and no less perverse. Following the path of deleuzian provocation, they affirm that the racist practices should not be understood so much in terms of binary divisions and exclusions, but as a strategy of differentiated inclusion. According to these authors, white supremacy works, preferentially, by first attracting otherness and then structuring the differences according to the degree of deviation from whiteness. Far from affirming that there is no more racial exclusion in the contemporary world, they understand that it arises as a result of a differentiated inclusion. This new racism appeals, then, to culture to fulfill the role that biology once played. In this way, the theoretical replacement of race or biology by culture paradoxically becomes a theory of race preservation, that is, of the perpetuation of racism. However, we believe that to understand the relationship between cultural backgrounds and racialization, other ideas are also important. In response, we turn to Ann Laura Stoler [3], to look historically at colonial racism, its structuring around discourses that produced "cultural competencies" and "processes of education of desire". In the author's use of Foucault, the articulation between the individual body and the body politic (through micromanagement of the first, micro-vigilance of the second, and of the control circuits that exist between the two) constitutes biopower. This is the condition of the existence of racism in its current form, and such configuration also makes sense in the colonial context. If, on the one hand, quoting Negri \& Hardt [4], there is the pretense that imperialism and colonialism are no longer so important in the elaboration of contemporary differential racisms, we propose an analysis of the "colonial archives" to see to what extent a whole relationship between the construction of racial categories is still relevant to an expanded understanding of the critique of the modulation of racial identities today. We also seek to make a critical review of accusatory categories such as "identitarism" and "essentialism".

\subsection{The Discursive Explosion of Identity and the Issue of Essentialism}

Many authors call attention to the growing movement of debates around identities starting at the end of the 20th century. Close to entering the third decade of the new century, the debate is still evident. The many different perspectives and the varied analyzes that can be done of that "resurgence" of identities try to understand the phenomenon not as something with a single motivation or the result of a single process. Jesus Martin-Barbero understand this movement as a result of a plot of reasons and motives that articulate "neglected historical claims, territorial claims, tenacious racial prejudice, religious exaltations, sudden cleavages memory, long struggles for recognition and, through all these materials, putting them to a boil, old and new power struggles" [5]. For the author, however, in Latin America, this analysis must be done from three strategic areas: the traditional communities, the national culture and the new urban communities.

In that sense, it is interesting and productive to reflect on identity in its relationship with culture, based on the discussion proposed by Garcia Canclini [6] and the notion of cultural hybridization. This concept allows us to reflect on the crossings, dynamics and traverses experienced historically, and still today, by the different fields of practices and cultural meanings. The author considers the sociocultural formations from agreements and negotiations between the traditional cultures and the others from the process of colonization. For Canclini besides the traditional cultures, which shape the contemporary sociocultural formations, also the migratory processes -historical and contemporary- and the emergence of movements and demands within the modernity, as the feminist and LGBTIQ movements, among others, are constitutive of cultural hybridity. In its definition, hybridization refers to "socio-cultural processes in which discrete structures or practices, which existed separately, combine to generate new structures, objectives and practices" [7]. The author emphasizes, however, that traditional cultures themselves are the result of hybridizations, so that there are no "pure sources" and that these fusions do not always occur in a planned way, but almost always, be it in the arts or in life Everyday "hybridization arises from individual and collective creativity"[8], where the strategy of cultural reconversion [9] allows to insert knowledge, techniques, 
technologies and capacities in new conditions of production, market and, I add, consumption. Hybridizations have experienced a "spectacular multiplication" in the twentieth century and globalization energizes its process.

In Who Needs 'Identity'?, Stuart Hall [10] makes stimulating comments about what he considers to be a paradoxical phenomenon that is marked by discursive explosion around the concept of "identity" and a complete deconstruction of identity perspectives. According to the author:

Within the anti-essentialist critique of ethnic, racial and national conceptions of cultural identity and the 'politics of location' some adventurous theoretical conceptions have been sketched in their most grounded forms. What, then, is the need for a further debate about 'identity'? Who needs it? [11].

For Hall "Identity is such a concept - operating 'under erasure' in the interval between reversal and emergence; an idea which cannot be thought in the old way, but without which certain key questions cannot be thought at all" [12]. Questioning the concept of identity means working with this concept in a partialized and deconstructed way, moving beyond its original paradigm. In his reflection, he also reveals his point of view sourced from Foucault, particularly in relation to its defense of a decentering of the subject in the direction of discursive practice. It is not, says Hall, a total abandonment or an abolition of the subject, but rather a reconceptualization. He tries to establish an anti-essentialist use of identity, by emphasizing that the concept of identity that he develops is a strategic and positional one [13].

From the processes of globalization and migration (forced or "free"), Hall considers that "the origins", "the traditions", and "the common past" invoked and claimed by the different identities at stake are more in the order of invention and negotiation with the routes than a return to the origins. Its fictional character, the author emphasizes, does not diminish its discursive, material or political efficacy. In these terms, identities "are more the product of the marking of difference and exclusion, than they are the sign of an identical, naturally-constituted unity - an 'identity' in its traditional meaning" [14]. There is, therefore, a series of internal differentiations and seams within the same identity. Hall considers that the identification process is not about a unilateral act, but about an articulation. The author continues to use the term "identity":

to refer to the meeting point, the point of suture, between on the one hand the discourses and practices which attempt to "interpellate", speak to us or hail us into place as the social subjects of particular discourses, and on the other hand, the processes which produce subjectivities, which construct us as subjects which can be "spoken". [15]
The identities are, in that way, understood as "points of temporary attachment to the subject positions which discursive practices construct for us, (...) the result of a successful articulation or 'chaining' of the subject into the flow of the discourse" [16].

Identities are always established in a relational manner. What distinguishes one identity from another are characteristics chosen or not by those who belong to a certain group. These characteristics can be of an ethnic, religious or gender nature, based on genetic, historical or territorial aspects. These are aspects that in many cases are subject to subjectivities and always imaginary, collective or individual, and power relations. It should be noted that identities are not unique, and a subject can be identified with different groups (women, homosexuals, Afro-descendants, from a peripheral country), including identities that are contrasted, as, for example, in recent cases of identity clashes national of European countries with Muslim identity.

We understand identity as a position of the subject, which can be related to behavioral, genetic factors (sex, skin color, physical features) and / or symbolic (culture, religion, history). As said, the constructions that the subjects that identify with a certain group make of these referents are not fixed, they are in a constant flow of changes and different affirmations; and in a globalized context, identities are increasingly exposed to diverse cultures and interact in that process. According to Martín-Barbero, individuals now "live a partial and precarious integration of the multiple dimensions that make them up. The individual is no longer the indivisible, and any unit that is postulated has a lot of 'imagined unity"' [17].

In this panorama of identities, what is intended is to shed light on the complexity of these processes and highlight relevant aspects of the contemporary social fabric where they are inserted. They are fundamental movements to understand the conformation of Latin American societies, articulated as already said, between the traditional, the national and the new urban communities. The latter, the main space where today the battle of identities is being fought, especially those that, in addition to rights and public policies of recognition and inclusion, demand the change of the racist, macho and Eurocentric logic that has determined the ways of modernity. coloniality the new urban communities represent, according to Martín-Barbero, new ways of being together, related to the way in which the various continuous flows -mainly, but not only, the informational flow- reconfigure the ways of being, being and using the city. They are flows that also permeate life in the countryside and end by pointing to the formation of a virtual city, "space of a new sensorium whose emergence is closely linked to the movement that links the expansion / explosion of the city with growth / densification of the media and electronic networks" [18]. 
This broadening of the discussion about identities is also accompanied by a debate on the issue of essentialism. In his essay What is this 'black' in the black culture? Stuart Hall [19] discusses the issue of essentialism from the relationship between politics and culture, present in cultural policies that establish the meanings of popular culture and black culture. For Hall, it is not a case of thinking about culture through a binary logic that identifies oppositions, such as: authentic/inauthentic; scholarly/popular; resistance/co-option. Black popular culture would be, according to this logic, a "space of strategic contestation"that" has enabled the surfacing, inside the mixed and contradictory modes even of some mainstream popular culture, of elements of a discourse that is different - other forms of life, other traditions of representation" [20]. It is necessary to recognize that, in black popular culture there are no pure forms:

Always these forms are the product of partial synchronization, of engagement across cultural boundaries, of the confluence of more than one cultural tradition, of the negotiations of dominant and subordinate positions, of the subterranean strategies of recoding and transcoding, of critical signification, of signifying. Always these forms are impure, to some degree hybridized from a vernacular base. Thus, they must always be heard, not simply as the recovery of a lost dialogue bearing $[. .$.$] what they are - adaptations, moulded to$ the mixed, contradictory, hybrid spaces of popular culture. They are not the recovery of something pure that we can, at last, live by. [21]

Hall finds that some "essentialism" was, in fact, historically necessary in the battle for space in the field of mainstream popular culture. He understands that the "strategic essentializing" encapsulated in the "black" signifier, was necessary at a certain moment. Despite recognizing the historical value of the "essentializing moment", Hall raises the question of "whether we are any longer in that moment, whether that is still a sufficient basis for the strategies of new interventions" [22]. As Hall suggests, it is necessary to move forward in a movement beyond that which essentializes differences, understanding their own differences from other kinds of differences.

Thus, Hall's ideas put an end to the naive concept of an essential black subject and an end to the use of black as a category describing essence, since the blackness of a subject, beyond not serving to summarize an identity, carries with it contradictions and connections to other identities: "There is no guarantee, in reaching for an essentialized racial identity of which we think we can be certain, that it will always turn out to be mutually liberating and progressive on all the other dimensions [23]."

To Bell Hooks [24], a critique of essentialism that challenges only marginalized groups to interrogate their use of identity politics or an essentialist standpoint as a means of exerting coercive power" can leave unquestioned the "critical practices of other groups who employ the same strategies in different ways and whose exclusionary behavior may be firmly buttressed by institutionalized structures of domination" [25].

In the same way, Avtar Brah [26] proposes the following argument: if "essentialism" refers to a notion of ultimate essence that would transcend historical and cultural limits, then, we should ask "at what point, and in what ways" "does the specificity of a particular social experience become an expression of essentialism?" [27]. So, it would be necessary to question to the racialization of white subjectivity, taking into consideration that both blacks and whites experience their gender, class and sexuality through race. The author understands that this racialization of white subjectivity is not so visible to white groups, for "white" operates as a "signifier of dominance." The terms "white woman," "black woman," "white men," and "black man," are not just descriptive terms but hierarchically organized categories in certain economic, political, and cultural circumstances [28].

From the contribution of contemporary social criticism composed of different authors, schools of thought and production of knowledge in networks and social movements - it became possible to conceive identities as unstable, marked by ambivalences and ambiguities. Thus, the fixation of identities is always the effect of relations of power and knowledge that conceive the body of individuals and populations as the object of their intervention. In view of this critical look at racial identities, one can no longer simply celebrate them naively as an ideal place and unifier of resistance to power; however, this does not authorize a posture that would demonize and definitively discard them, given their contested and changeable character. So, identities, and with it, we understand both the intellectual debates that accompany them and the social and political uses made of them, can represent as much places of challenge and subversion of the instituted powers as places of reaffirmation of these powers.

Thinking towards the understanding of an Afro-Ecuadorian identity, the traditional has often been in conflict with the national. The latter, since its conception, has excluded the traditional elements of an Afro-Ecuadorian culture from its constitution. In global times of multiculturalism and new urban / virtual communities, these exclusions begin to emerge. Not purely and without conflicts, but the affirmation of excluded identities represents a change, both in the ways of perceiving those who identify with them -by means of the recognition of their rights, inclusion of their cultural elements in the national imaginary, in addition to adopting affirmative policies and combating racism - as in the way that Afro-Ecuadorians themselves recognize and relate to their identity, culture, history and condition.

\section{The Imagined Ecuador}

To reflect on the articulations of the communicative 
contexts with the forms of racism towards Afro-descendant people in Ecuador is, first of all, to think about the same country in its most varied connotations. What is Ecuador and how, from its real and imagined limits, can a group (in this case the Afro-Ecuadorians) be part of and at the same time excluded from it? This is because thinking about the forms of exclusion of certain groups and the prevalence of others in societies throughout history cannot be done without first understanding the elements that make up that society. Thus, to understand racism towards Afro groups in their various expressions, is to understand what constitutes the society where this racism operates, as well as the elements of differentiation that are attributed to Afro-descendants in this context. Indeed, racism towards people of African descent is a practice that is reproduced throughout almost the entire planet. We are not interested here in going deeper into this process in a generic way but rather in focusing on its particularities within the Latin American and Ecuadorian society.

The formation of an Afro-descendant population in Ecuador originated from the same process as other countries on the American continent during the period of European colonization. In this country, this population was also originally constituted of people violently torn from their familial, community and territorial contexts and taken into forced labor in other lands [29]. What caused these people to be chosen to suffer such violence was, among many other factors, the understanding, from white European ethnocentrism, that they were biologically, morally, and culturally inferior. Although throughout the 20th century official voices from governments and science have refuted the biological existence of human races, that notion continues to permeate the imaginaries of common sense to the present day, in different ways.

In the 19th century the processes of independence and formation of the Latin American national states began, which, although they were followed by the abolition of slavery, did not represent a break with the "civilizing" colonial project. Ecuador as an independent nation emerged in the year 1830, with the disintegration of Gran Colombia, and in 1854 the "abolition" of slavery was declared. However, the independence process occurred from white-mestizo sectors based on an ideology of miscegenation, "proclaiming the mestizo as the archetype of the Ecuadorian national identity, deliberately and systematically excluding Afro-Ecuadorians from the idea of national identity" [30]. This is the point where it is important to understand what is meant by "idea of national identity" and the "narrative of the nation" and what elements these entail.

In Ecuador, and in almost all of Latin America, modern national states have been formed from a strategy based essentially on the symbolic with indisputable political and social consequences. It is what Benedict Anderson [31] calls "Imagined Communities", when describing nations as groups of people who share an imaginary social. That is to say, the modern nation is a semiotic construction that is signified by certain signs that are constituted as identity devices, to which Guillermo Bustos adds: "[...] it comes from, among other sources, the active role played mainly by social memory, promoted by the State in an official way, as a matter of identity" [32]. However, that symbolic construction is not without conflicts, Homi K. Bhabha talks about the ambivalence of the nation's narratives from two temporalities: the pedagogical, continuous and cumulative; and the performative, repetitive and recursive:

The pedagogical founds its narrative authority in a tradition of the people, described by Poulantzas as a moment of becoming designated by itself, encapsulated in a succession of historical moments that represents an eternity produced by self-generation. The performative intervenes in the sovereignty of the nation's self-generation by casting a shadow between the people as 'image' and its signification as a differentiating sign of Self, distinct from the Other of the Outside. [33]

\subsection{Modernity as a Referent}

Modernity is a fundamental and foundational element of Latin American national states. A consensus among the many perspectives of this concept is that independent Latin America, imagined and narrated from miscegenation, is born with its eyes fixed on the promises of modernity. Thus, it is worth discussing what modernity is, as a referent for the construction of national narratives in Latin America.

For Jorge Larraín [34], modernity, although born in Europe around the 16th century, is a movement with a globalizing tendency, which, by connecting with different realities, assumes varied trajectories and configurations. From this perspective, Latin America entered the movement late in the 19th century, and incompletely. According to the author, while the movement in Europe is mainly characterized by the industrial revolution, political liberalism and its illustration, in Latin America, the modern project was given priority in political and cultural arenas to the detriment of the economic and yet with significant limitations:

Its first phase during the $19^{\text {th }}$ Century could be called, with some degree of contradiction, oligarchic, due to its restrictive character. [...] First, in this phase, liberal ideas are adopted, secular education expands, a republican state is built and democratic forms of government are introduced, but all this with, in effect, extraordinary restrictions on the broad participation of the people. Second, unlike the European trajectory, industrialization is postponed and replaced by a system of export of raw materials that keeps the productive sectors back. [35]

The "restrictive character", mentioned by the author, is 
due to the fact that, for Larraín, the oligarchies that promoted modern Latin American projects from the independence processes, had as their goal the complete replacement of the indigenous and African cultural elements present in those societies with a eurocentric model. Thus, the idea of "race improvement" adopted by the State as policy, prevailed, whether deliberately or covertly. The author observes that, even in Europe, there was a certain distance between the discourse of modernity and its respective translation into effective social practices.

Walter Mignolo [36] draws attention to a "hidden dimension of events". For him, in the celebration of modernity lies the devaluation of life, that is, "human lives became dispensable for the sake of increasing wealth, and this dispensability was justified by normalizing the racial classification of human beings" [37]. For Mignolo, there is no modernity without coloniality, one is a constituent part of the other, as the two sides of the same coin. The author identifies that, throughout the last 500 years (1500-2000), a rhetoric of modernity was characterized by four versions: first, led by Christian theology, the discourse of salvation prevailed in the form of conversion; led by France and England, this discourse was replaced by civilizing rhetoric; then, in illustration, it was complemented with the idea of progress; and, finally, after the Second World War, under the leadership of the United States, it also incorporated the rhetoric of development. Under that rhetoric, however, the logic of coloniality is hidden, acting in four interrelated areas: control and management of subjectivities, control and management of authority, control and management of the economy and control and management of knowledge. It is important to emphasize that for Mignolo, the modern project was born as an exclusively European idea, and that, therefore, its projection onto other contexts has resulted in a series of "upstart" modernities.

The centrality of racialization in the modern/colonial project is also highlighted by Aníbal Quijano [38], for whom the mental construction of race is the basic experience of colonial domination, present up to the present day in the most important dimensions of world power. The author considers that the colonization of Latin America was what led to the modern sense of race that "produced historically new social identities in America: indigenous, blacks and mestizos and redefined others" [39]. In the configuration of the relations of domination, race was the instrument of population classification. The conformation of political powers in the hands of a white-mestizo minority in the colonized territories of Latin America resulted in the paradox of independent states and colonial societies. According to Quijano, racialization is so decisive in the formation of independent states in Latin America, that it even delayed the industrialization of these countries, since converting commercial capital into industrial capital implied freeing indigenous serfs and black slaves and turning them into salaried workers:

The dependence of the capitalist gentlemen did not come from national subordination. This was, on the contrary, a consequence of the community of racial interests. [...] The subordination came later, precisely because of the dependence, and not the other way around: during the world economic crisis of the $30 \mathrm{~s}$, the bourgeoisie with more commercial capital in Latin America (Argentina, Brazil, Mexico, Chile, Uruguay and, to some extent, Colombia) was forced to produce the goods that were serving for their ostentatious consumption locally, that they previously had to import. This was the beginning of the peculiar Latin American path of dependent industrialization [40].

It is interesting to perceive from the contributions of these authors how racialization is the axis that leads to the conformation of Latin American national states. For this essay it is important to remember that this conformation, after independence of Spain and Portugal, is comprised of diachronically accumulating narratives articulating, on the one hand, an identity process constituted by "historical sedimentation", and on the other, the present of the history of the people, in "the fluctuating movement that the people are just giving shape to" [41]. It is in that that power is constituted in the figure of the state, controlled by white-mestizo oligarchies, essentially racialized, in which the rhetoric of modernity (salvation, civilization, progress and development) and the logic of coloniality (control of subjectivities, authority, economy and knowledge) are present. It materializes in official narratives (radio, TV, press, literature, cinema) and national signs, but also in the "performative temporality", mainly of subaltern groups that, from their marginality, look for identity in the liminality of modernity, that is, in the rejection of that "official" past, its rereading and its resignification. According to Bhabha [42], it is this ambivalence of the nation that allows its displacement every time it is narrated. In Ecuador it is what has allowed the emergence of the narratives of the modern white-mestizo country and its displacement to the contemporary intercultural and plurinational State.

\subsection{Postmodernity and the Multicultural Trend}

As we try to describe in the previous section, Ecuador as a nation arises from the processes of independence of Latin America as a pseudo-modern country. "Pseudo" for the upstart adoption of the European project based on liberalism/industrialization/illustration, and "modern" because it maintained its colonial social structure, founded mainly on racial classification and hierarchy. However, a consensus issue in the debates about modernity is that the 20th century represented the crisis of its project. One of the best-known analyses of this process was made by 
Zygmunt Bauman, who considers that the crisis of modernity was a transition from its solid phase to its liquid phase:

I use the term 'liquid modernity' here for the currently existing shape of the modern condition, described by other authors as "posmodernity", "late modernity", "second" or "hyper" modernity. What makes modernity "liquid", and thus justifies the choice of name, is its self-propelling, self-intensifying, compulsive and obsessive 'modernization', as result of which, like liquid, none of the consecutive forms of social life is able to maintain its shape for long. [43]

Walter Mignolo, for his part, describes this process as follows:

During the last quarter of the 20th century, modernity was questioned in terms of its chronology and ideals, both in Europe and in the United States: the term postmodernity refers to these critical arguments. Recently, in Europe, altermodernity is emerging as a new term and period. Spatially, expressions such as alternative modernities, subaltern modernities or peripheral modernities were coined to account for modernity from non-European perspectives [44].

The author also draws attention to the fact that these arguments and narratives are either focused on Euro-American modernity or put themselves in a subordinate position to that model, ignoring the colonial aspect of modernity and the revindication of the non-western world for its deconstruction and the proposition of other "non-western" modernities. For the purposes of this essay, we use the term postmodernity as an attempt to agglutinate the perspectives of that crisis to what we are interested in here: its consequence and specificities from and in Ecuador and Latin America. It is important for us to understand what this crisis represents for the model of racial classification and hierarchy inaugurated by the European modern/colonial project in Latin America and carried forward by the white-mestizo oligarchies responsible for the processes of independence and conformation of the national states in this region.

In this way, Stuart Hall [45] helps us establish a relationship between the postmodern context and the multiculturalist inclination of national narratives. For him, the change in late modernity, particularly "globalization", has a specific character and an impact on cultural identity. Modern western societies, "product of conquests, absorptions of one people by another" [46], have a hybrid character: despite the modern efforts and attempts to establish a national culture, this has not been more than an ethnic jumble to which the designation of "people" has been assigned. Hall claims that this "hybridity" of the modern nation-state: [...]in the present phase of globalization, being compounded by one of the largest forced and unforced mass migrations of recent times. So that, one after another, Western nation-states, already "diaspora-ized" beyond repair, are becoming inextricably "multicultural" - "mixed" ethnically, religiously, culturally, linguistically, etc. [47].

Thus, the model of a unified national culture, prevalent in the narratives of modern states at the beginning of the 20th century, becomes, in a postmodern context, multiculturalist. However, contrary to what it may seem, this multicultural turn is not necessarily positive. Stuart Hall himself speaks of the "umbrella" character of the term, which had been appropriated in different ways by different groups to describe diverse and inconclusive political projects and strategies [48].

According to Catherine Walsh, in the Latin American context, the most used referent at the state level is pluriculturalism, i.e., "the recognition of existing diversity, but from a centric perspective of the dominant and 'national' culture". The author distinguishes between this and multiculturalism, which according to her is a descriptive term, with liberal bases of individual rights and equality, and one that refers to the multiplicity of cultures that exist in a society without necessarily establishing a relationship between them. Walsh proposes interculturality as the way forward, since it has an epistemic character that "allows an equitable interrelation between peoples, individuals, knowledge and culturally different practices" [49]. For this author, the inadequacy of the multi or pluriculturalist senses adopted by contemporary states is expressed mainly in the attempt to incorporate or include ethnic diversity within essentially white and Eurocentric social, political and knowledge structures. In them, afro and indigenous take secondary place, "as 'local' and folklorized wisdom before 'scientific and universal' knowledge (read: Eurocentric)" [50].

In Ecuador, the 1998 Constitution was the first to recognize the existence of Afro-Ecuadorian peoples with the guarantee of their collective rights. In that document, however, Afro-Ecuadorians appear as a kind of other indigenous, that is, the same rights are recognized "Whenever applicable [to their specific situation(s)]" [51]. This concerns what many authors recognize as a condition of even more complex subalternity of the Afro peoples in relation to the indigenous. In addition to the practices of racialization and racism, the Afros also experience invisibility with regard to indigenous and white-mestizos. This inequality is what Juliet Hooker identifies as "the automatic appreciation by Latin American elites in different national contexts of indigenous peoples as other 'ethnocultural' and Afro as other 'racial'" [52]. The multicultural sense remained in the 2008 Constitution. In it, according to Jean Rahier's analysis, although progress 
is noted concerning specificities about the Afro-Ecuadorian people, there are few differences in relation to the 1998 document. In the analysis mentioned, Rahier adds a reading of the report made by the constituent assemblywoman Alexandra Ocles about the progress of inclusion in the 2008 Constitution of articles referring to the rights of Afro-Ecuadorian people, on which she affirms that:

[...] although Afro-Ecuadorians involved in the process were not successful in preventing the kind of distinction that continues to be established between the collective rights of indigenous and Afro-Ecuadorian peoples [...], they were successful in convincing the assembly members [...] to do two things: (1) include an unambiguous wording that clearly recognizes Afro-Ecuadorians as "people" [...]; y (2) prohibit the use of the term black in the constitution [53].

\section{Thinking about Communication}

Considering the foregoing in this essay, we believe that the Ecuadorian ethno-racial question in the contemporary context cannot be thought of apart from the notion of modernity/coloniality, from its racialized foundations and its current expressions: postmodernity and multiculturalism. However, we still consider that contemporaneity has an equally relevant element that cannot be left aside: the centrality of communication. That is, the post-modern and multicultural context is also mediatized, not as simple descriptive characteristics, but as constitutive of the same reality. That "centrality of communication" is a view shared by many authors. With different nuances, those who are inclined to reflect about contemporary social relations have not been able to ignore the communicational interweavings caused mainly by technological advances. Communication and its technological changes have accompanied and paved the way for the "progress" of modern societies for a long time, such that modernity itself would not be possible without technological communication. In fact, the invention of the printing press by Guttenberg and the consequent possibility of mass printing of texts and books can be considered as one of the first features of European modernity.

In this sense, Scott Lash [54] gives us a perspective about transformations in modernity, understanding them as regimes of signification that produce cultural objects whose circulation and modes of signification are the dimensions of interest. For this author, one of the most significant movements of modernity was the shift in control of the means of production based on a cumulative logic to the control of circulation based on a communicative logic. From this perspective, we can think of modernity in cultural/communicational terms as a cumulative and progressive process that begins in a system of signification oriented by printing, theater, music and literature; which continues in the 20th century by adding the technical reproducibility of the Cultural Industry, as well as film, photography and new mass media, such as radio and television; and which, in the 21 st century becomes what Álvaro Cuadra describes as a "cultural hyperindustrialization", which:

[...] takes the basic trends of modernity to the extreme, implanting new memory technologies that take the form of digitized networks available to hypermassive publics, no longer according to the vertical model of transmission, with a single transmitter that talks to undifferentiated and anonymous masses, but according to a customized model that moves the figure of the passive receptor/consumer to the interactive "user" [55].

But if communicational processes are in tune with transformations in modernity, they are further constitutive of it and its changes, and it is important to think how that articulation occurred in Latin America. That is because, as we propose in this essay, the modern project is not possible without coloniality, and its consequent adoption/adaptation in the aforementioned continent, has never finished - maybe this has not even been of interest. Thus, it is not just a matter of imagining how modern cultural, communicational and media expressions are constituted in Latin America, from colonialism to the advent of Cultural Industries and their consequent digitalization and globalization of production, circulation and consumption. It is also about the way these essentially modern (and thus, colonial) elements are articulated to local contexts, configuring and being configured by subalternized cultures, logics and modes of thought from the "coloniality of power" [56].

\subsection{Communication and the "Modern" Ecuador}

Since the first moments of the Latin American nation-states, after the processes that led to their independence, the press has played an important role in the construction of the public sphere. According to Julio Ramos, journalism "was the basic means of distribution of writing, [...] the place where 'rationality', 'illustration' and 'culture' were discussed" [57]. In Ecuador, although many works analyze the referents that shaped the imaginary Ecuadorian and the narrative of the nation throughout the second half of the 19th century and the first half of the 20th century, few details the communicational articulation of these processes. Hernán Ibarra [58], for example, talks about the construction of national heroes and symbols, the institutionalization of Castilian, the creation of an idea of territorial borders and the strategy of cultural homogenization through an ideology of miscegenation, as referents of the feeling of nationhood generated by a minority in Ecuador, however, he does not explain how this process occurred. 
The historian Guillermo Bustos [59], in his $\mathrm{PhD}$ thesis in which he analyzes the "creation" of Ecuador through the memory of the nation, posits that the book Resumen de la Historia del Ecuador desde su orijen hasta 1845, in 1870, was the first national "storytelling". The book is authored by Pedro Fermín Cevallos, of whom Bustos says that "his first forays into the field of the historical report appeared in the form of press articles in La Democracia, in 1855". Enrique Ayala Mora also describes the use of the press, mainly in the nineteenth century, as an instrument to promote the official culture and idea of Ecuador, however, he cautions that, "the participation of the press in the constitution of Ecuador as a nation is very important and practically has not been studied" [60]. The same author adds that, although the Ecuador of that period consisted of a mostly illiterate country, some practices, such as the reading aloud of the whole newspaper in "social circles", by the parish priests in the pulpit of the churches, or in stores, at the request of illiterate clients assigned newspapers a high power of influence.

The first half of the 20th century brought with it the industrialization of the country and the consequent advent of cultural industry and mass communication, promoted mainly by radio and, later, by television. In Ecuador, the radio appeared at the end of the 1920s and it had his peak in the 50s, with the phenomenon of radio theater [61]. However, as the first mass media to reach popular success, radio is also the first "space" where an interaction of the culture of subaltern indigenous and Afro groups is expressed, which in Gramscian terms, negotiate the use of this medium [62]. Television arrived in the country in the 1950 s, and reached popularity in the late 1960s, following in the footsteps of radio, driven mainly by the dramaturgy of imported productions. However, although this profile remains to this day, television has managed to consolidate and become the most popular and influential medium in the entire country [63].

\subsection{New Contexts, New Paradigms?}

This brief history that we have tried to present is intended to establish a more direct relationship between the advent of mass media in Ecuador and the strategies of promoting a unified national narrative based in the elements previously developed in this article (modern/colonial and racial). However, what we defend here is that the advent of Cultural Industry and the technologies of mass communication in Ecuador and Latin America goes beyond a mere instrumental function, that is, Cultural Industries (and within them, the media), are a product of modernity which ends up reconfiguring it. This reconfiguration is related to the digital explosion that began at the end of the twentieth century, globalization, and the conformation of lifestyles saturated by the logic of communication and information technology devices, but also by the appropriation, uses and meaning that the receptors/consumers of these media and their contents constantly make.

It is in the context of this debate that we propose to launch a communication review that goes beyond the involvement of the media as a reproducer (or even a producer) and a potentiator of discourses about race, as well as the role of new technologies as tools of resistance or oppression of subjects. What we do is propose ways forward, starting points to think through broader communicational implications to the debate about identities and consequently, contemporary race and racism. Thus, it is important to think through what has been said from the process of mediatization of cultures. If this is the space for the conformation of identities in postmodernity, the structural character of technological mediation of communication cannot be ignored [64]. According to Graziela Bianchi, "talking about the process of mediatization means talking about how the media operates in different spheres of society and, even, inside cultures. They begin to act, in this case, as possibilities for building identities, imaginaries, and mediatized cultures" [65]. To this, María Cristina Mata suggests a process of mediatization of experiences, that is, she proposes that the media act as the central producers of reality, as "guarantors of the possibility of being and acting" [66]. This perception is in accordance with what Muniz Sodré says; for him post-industrial society "is governed by the virtualization of human relations, present in the articulation of institutional multifunctioning and of certain individual behavior patterns with communication technologies" [67]. This same author proposes an immediate social ethic (he names ethicality) as a product of the media - new or traditional-, that act on customs and routines, guiding behaviors and attitudes.

The contribution of Jesús Martín-Barbero [68] is to try to relate, culture, identity and communication in this mediatized context. For him, identity and technicality are the two processes that have radically transformed the place of culture at the end of the 20th century. We have problematized the place of identity in the previous sections; on the technical side, however, Martín-Barbero clarifies that it is not just a number of new technological devices that are increasingly accessible, but a new form of production of the symbolic, which constitutes the culture [69].

Therefore, technological communication is today the way to interact with the world, to relate socially, to produce meaning, and to recognize oneself; is finally, constitutive of cultural identities themselves. We cannot think about the place of race and racism in postmodernity without considering the implications of cultural contexts constituted and constantly traversed by contemporary communicational logic.

\section{Conclusions}

This article is part of the reflections from works still in 
development at this time. Here, what we have proposed are some ideas to think through the constituent elements of that what can be considered the Afro-Ecuadorian identity. Our proposal has not been to present a supposedly "true" identity, or even the criteria or referents to determine what that identity is, but rather to seek to gather some elements that we consider useful for a critical analysis of the social and political processes that racial identities produce in the Ecuadorian and Latin American modern/colonial context. It is from there that we have articulated and discussed some important elements that go into the configuration of contemporary racial identities, such as: identity, race, modernity/coloniality, multiculturalism, and communication.

The objective of these concepts and categories, to and from the Latin American post-colonial context, is not to draw conclusions, but to establish some basis for deepening a critical look at the pertinence of the relationship between the Afro-Ecuadorian identity and the contemporary contexts of mediatized communication.

\section{REFERENCES}

[1] Michel Foucault, Em defesa da sociedade: curso no Collège de France (1975-1976), Martins Fontes, São Paulo, 2005.

[2] Antonio Negri y Michael Hardt, Imperio, (Traducción: Eduardo Sadier), Harvard University Press, Cambridge, 2000.

[3] Ann Laura Stoler et al., La chair de l'empire: savoirs intimes et pouvoirs raciaux en régime colonial, La Découverte: Institut Emilie du Châtelet, Paris, 2013.

[4] Antonio Negri y Michael Hardt, Imperio, (Traducción: Eduardo Sadier), Harvard University Press, Cambridge, 2000.

[5] Jesús Martín-Barbero, "Identidades tradicionales y nuevas comunidades en tiempos globales", en Identidad, cultura y politica: perspectivas conceptuales, miradas empiricas, de Gabriela Castellanos, Delfín Ignacio Grueso, y Mariángela Rodríguez (México, D.F.: H. Cámara de Diputados, LXI Legislatura: Miguel Ángel Porrúa; Universidad del Valle, 2010), 77 .

[6] Néstor García Canclini. Culturas híbridas: estrategias para entrar y salir de la modernidad. Nueva ed. Estado y sociedad 87. Buenos Aires: Paidós, 2001.

[7] Ibid. 14

[8] Ibid. 16.

[9] Néstor García Canclini defines cultural reconversion as strategies by which a painter becomes a designer, or the national bourgeoisies acquire the languages and other skills necessary to revert their economic and symbolic capitals in transnational circuits

[10] Stuart Hall, Introducción: ¿Quién necesita identidad?, Cuestiones de identidad cultural, Amorrortu, Buenos Aires,
2003.

[11] Ibid. 13.

[12] Ibid. 14.

[13] Ibid. 17

[14] Ibid. 18.

[15] Ibid. 20.

[16] Ibid.

[17] Jesús Martín-Barbero, "Identidades tradicionales y nuevas comunidades en tiempos globales", 82.

[18] Ibid. 20.

[19] Stuart Hall, ¿Qué es ‘lo negro' en la cultura popular negra?, Biblioteca Virtual Universal, Buenos Aires, 1995.

[20] Ibid. 7.

[21] Ibid. 8.

[22] Ibid. 9.

[23] Ibid. 10.

[24] Bell Hooks. American Literary History. Vol. 3, No. 1 (Spring, 1991), p. 172-183.

[25] Ibid. 176.

[26] Avtar Brah. Difference, diversity, differentiation, International Review of Sociology (Revue Internationale de Sociologie, 1991), 2:2, 53-71

[27] Ibid. 53.

[28] Ibid.

[29] Mery Elizabeth Astaíza, El pueblo afrodescendiente en el Ecuador, Informe Temático, Defensoría Del Pueblo del Ecuador, Quito, 2012, 10-14.

[30] José F. Chalá Cruz, Representaciones del cuerpo, discursos e identidad del pueblo afroecuatoriano, Abya-Yala; Universidad Politécnica Salesiana, Quito 2013, 15.

[31] Homi K Bhabha, El lugar de la cultura, Ediciones Manantial, Buenos Aires, 2002.

[32] Guillermo Bustos, La urdimbre de la Historia Patria. Escritura de la historia, rituales de la memoria y nacionalismo en Ecuador (1870-1950), University of Michigan, 2011, 109.

[33] Homi K Bhabha, El lugar de la cultura, Ediciones Manantial, Buenos Aires, 2002, 184.

[34] Jorge Larraín, La trayectoria latinoamericana a la modernidad, Estudios Públicos, vol 66, 313-333, 1997.

[35] Ibid. 319.

[36] Walter Mignolo, La colonialidad: la cara oculta de la modernidad, Museo de Arte Contemporáneo de Barcelona, Barcelona, 39-49, 2009, 41.

[37] Ibid.

[38] Aníbal Quijano, Colonialidad del poder, eurocentrismo y 
América Latina, en La colonialidad del saber: eurocentrismo y ciencias sociales. Perspectivas latinoamericanas, de Edgardo Lander, CLACSO, Buenos Aires, 201-246, 2000.

[39] Ibid.202.

[40] Ibid.236.

[41] Fanon, quoted by Homi K Bhabha, El lugar de la cultura, Ediciones Manantial, Buenos Aires, 2002, 188.

[42] Homi K Bhabha, El lugar de la cultura, Ediciones Manantial, Buenos Aires, 2002.

[43] Zygmunt Bauman, La Cultura en el Mundo de la Modernidad Liquida Fondo De Cultura Económica, Mexico DF, 2013, 17.

[44] Walter Mignolo, La colonialidad: la cara oculta de la modernidad, Museo de Arte Contemporáneo de Barcelona, Barcelona, 39-49, 2009, 42.

[45] Stuart Hall, Sin garantías: trayectorias y problemáticas en estudios culturales, Envión editores, Popayán, 2010, 366.

[46] Ibid.554.

[47] Ibid.

[48] Stuart Hall, La cuestión multicultural, in Sin garantías: trayectorias y problemáticas en estudios culturales, Envión editores, Popayán, 2010, 583-618.

[49] Catherine Walsh, Interculturalidad, conocimientos y decolonialidad/Inter-culturality, knowledge and decolonialism, Signo y pensamiento, vol. 24, N. 46, 39-50, $2005,45$.

[50] Ibid.45.

[51] Ibid.46.

[52] quoted by Jean Muteba Rahier y Mamyrah Dougé-Prosper, Los afrodescendientes y el giro hacia el multiculturalismo en las 'nuevas' constituciones y otras legislaciones especiales Latinoamericanas: particularidades de la región andina, Revista de Estudos e Pesquisas sobre as Américas, Vol. 8, N. 1, 220-237, 2014, 225.

[53] Jean Muteba Rahier y Mamyrah Dougé-Prosper, Los afrodescendientes y el giro hacia el multiculturalismo en las 'nuevas' constituciones y otras legislaciones especiales Latinoamericanas: particularidades de la región andina, Revista de Estudos e Pesquisas sobre as Américas, Vol. 8, N. 1, 220-237, 2014, 223

[54] Scott Lash, Sociología del posmodernismo, Amorrortu, Buenos Aires, 1997.

[55] Álvaro Cuadra, Hiperindustria cultural, ARCIS, Santiago, 2007,8 .

[56] Aníbal Quijano, Colonialidad del poder, eurocentrismo y
América Latina, en La colonialidad del saber: eurocentrismo y ciencias sociales. Perspectivas latinoamericanas, de Edgardo Lander, CLACSO, Buenos Aires, 201-246, 2000.

[57] Julio Ramos, quoted to Guillermo Bustos, La urdimbre de la Historia Patria. Escritura de la historia, rituales de la memoria y nacionalismo en Ecuador (1870-1950), University of Michigan, 2011, 22.

[58] Hernán Ibarra y Victoria Novillo, Radio en Quito (1935-1960), Don Bosco, Cuenca, 2010.

[59] Guillermo Bustos, La urdimbre de la Historia Patria. Escritura de la historia, rituales de la memoria y nacionalismo en Ecuador (1870-1950), University of Michigan, 2011.

[60] Enrique Ayala Mora, La prensa en la historia del Ecuador: una breve visión general, Paper Universitario, Quito 2012, 11.

[61] Fernando Astudillo, La radio en Ecuador, in La radio en Iberoamérica: evolución, diagnóstico y prospectiva, de Arturo Merayo Pérez, Comunicación Social, Sevilla 191-201, 2007.

[62] Hernán Ibarra y Victoria Novillo, Radio en Quito (1935-1960), Don Bosco, Cuenca, 2010.

[63] Carlos Ortiz León y Abel Suing, La televisión ecuatoriana: pasado y presente, Razón y Palabra, Vol. 20, N. 93, 135-152, 2016.

[64] Jesús Martín-Barbero, Identidad, tecnicidad, alteridad. Apuntes para re-trazar el mapa nocturno de nuestras culturas, Revista iberoamericana, Vol. 69, N. 203, 367-387, 2003.

[65] Graziela Bianchi, Memórias midiáticas e midiatizadas - as relações que se estabelecem no âmbito da recepção radiofônica, in Processualidades metodológicas: configurações transformadoras em comunicação, de Jiani Adriana Bonin, Nísia Martins do Rosário, y Alberto Efendy Maldonado Gómez de la Torre, Insular, Florianópolis, 127$145,2013,129$.

[66] María Cristina Mata, De la cultura masiva a la cultura mediática, Diálogos de la comunicación, N. 56, 80-91, 1999, 87.

[67] Muniz Sodré, Eticidad y campo comunicacional, in Comunicación, campo y objeto de estudio: perspectivas reflexivas latinoamericanas, de Maria Immacolata Vassallo de Lopes y Raúl Fuentes N., ITESO, Guadalajara, 149-160, 2005,150 .

[68] Jesús Martín-Barbero, Identidad, tecnicidad, alteridad Apuntes para re-trazar el mapa nocturno de nuestras culturas, Revista iberoamericana, Vol. 69, N. 203, 367-387, 2003.

[69] Ibid. 369. 